\title{
ОСОБЛИВОСТІ ВИЯВУ ЕМОЦІЙНО-ВОЛЬОВОГО КОМПОНЕНТА САМОЕФЕКТИВНОСТІ В СТАРШОМУ ШКІЛЬНОМУ ВІЦІ
}

\author{
Федотова Тетяна, Малімон Людмила
}

\author{
Східноєвропейський національний університет імені Лесі Українки \\ Луцьк, Україна \\ Tafe-08@ukr.net,ur-1@ukr.net
}

У статті теоретично розглянуто проблему самоефективності особистості, яка являє собою не стільки здатність людей до усвідомлення своїх здібностей та їх найефективнішого застосування, скільки переконання особистості в спроможності й успіху в застосуванні компетенцій і набутого досвіду в певному виді діяльності. Виокремлено види самоефективності: діяльнісну, комунікативну та особистісну. У старшому шкільному віці самоефективність пов'язана 3 усвідомленням сенсу й мотивів навчання, автономністю, професійним самовизначенням, позитивним самоставленням, самоповагою, самокерівництвом i спроможністю до самоорганізації загалом.

Емпірично визначено такі особливості вияву емоційно-вольового компонента самоефективності в старшому шкільному віці: в осіб із самоефективністю нижчою від середнього рівня - це потреба відповідати ідеальному образу «Я» та бажання змін, незадоволеність, тривожність, сором'язливість і сумніви у своїх можливостях та здібностях, неспроможність контролювати власні емоційні стани й реакції; в учнів із середнім рівнем самоефективності - високий рівень самоприйняття, внутрішня конфліктність та самозвинувачення, рефлексія $з$ приводу власних недоліків і невдач, переживання почуття провини, проте прагнення доводити розпочату справу до кінця й мобілізація в подоланні перешкод, самоконтроль емоційних станів та реакцій; у діагностованих із самоефективністю вищою від середнього рівня - самовпевненість, усвідомлення власної цінності, самокерівництво, уявлення про себе як про вольову, енергійну й самостійну особистість, очікування визнання своєї цінності та унікальності зі сторони інших людей, високий рівень саморегуляції й наполегливості. Перспективу подальших розвідок у цьому напрямі вбачаємо у вивченні когнітивного та поведінкового компонентів самоефективності 3 урахуванням гендерного аспекту.

Ключові слова: самоефективність, здібність, саморегуляція, самоприйняття, самоповага, аутосимпатія, наполегливість.

Fedotova Tetyana, Malimon Ludmyla. Features of the Manifestation of the Emotional-Volitional Component of Self-Efficacy in Senior School Age. The article theoretically observes the problem of self-efficacy of personality, which is not

ISSN 2308-3743 (Online), ISSN 2227-1376 (Print)

(C) Федотова Т., Малімон Л., 2020. Ця стаття відкритого доступу на умовах CC BY-NC 4.0 
so much the ability of people to realize their abilities and their most effective use, as the beliefs of the individual in the ability and success in the application of competencies and experience gained in a particular activity. There are types of selfefficacy: activity, communicative and personal. In senior schoolage self-efficacy is associated with awareness of the meaning and motives of learning, autonomy, professional self-determination, positive self-assessment, self-esteem, self-management and the ability to self-organize in general.

The following features of the manifestation of the emotional-volitional component of self-efficacy in senior school age are empiricaly determined: in respondents with below-average self-efficacy - the need to meet the ideal image of «I» and the desire for change, dissatisfaction, anxiety, shyness and doubts about their posibilities and abilities, inability to control their own emotional states and reactions; in students with an average level of self-efficacy - a high level of self-acceptance, internal conflict and self-blame, reflection on their own shortcomings and failures, feelings of guilt, but the desire to bring the case to an end and mobilization in overcoming obstacles, self-control of emotional states and reactions; in respondents with above-average self-efficacy - self-confidence, self-worth, self-management, self-perception himself as a strong-willed, energetic and independent personality, expectation of recognition of their value and uniqueness by others, high level of selfregulation and persistence. We see the prospect of further exploration in the study of cognitive and behavioral components of self-efficacy, taking into account the gender aspect.

Key words: self-efficacy, ability, self-regulation, self-acceptance, self-esteem, autosympathy, persistence.

\section{Федотова Татьяна, Малімон Людмила. Особенности проявления эмо- ционально-волевого компонента самоэффективности в старшем школь-} ном воздасте. В статье теоретически рассматривается проблема самоэффективности личности, которая заключается не столько в возможности людей к осознанию своих способностей и их эффективному применению, сколько в убеждении личности в возможности и успехе в реализации компетенций и накопленного опыта в определенном виде деятельности. Выделяются такие виды самоэффективности, как деятельностная, коммуникативная и личностная. В старшем школьном возрасте самоэффективность связана с осознанием смысла и мотивов учения, автономностью, профессиональным самоопределением, положительным самоотношением, самоуважением, саморуководством и способностью к самоорганизации в целом.

Эмпирически определяются такие особенности проявления эмоциональноволевого компонента самоэффективности в старшем школьном возрасте: у школьников с самоэффективностью ниже среднего уровня - потребности соответствовать идеальному образу «Я» и желание изменения себя, неудовлетворенность, тревожность, застенчивость и сомнения в своих возможностях и способностях, неспособность контролировать собственные эмоциональные состояния и реакции; у учащихся со средним уровнем самоэффективности - 
высокий уровень самопринятия, внутренняя конфликтность и самообвинение, рефлексия по поводу собственных недостатков и неудач, переживание чувства вины, однако и стремление доводить начатое дело до конца, и мобилизация в преодолении препятствий, самоконтроль эмоциональных состояний и реакций; в диагностированных с самоэффективностью выше среднего уровня самоуверенность, осознание собственной ценности, саморуководство, представление о себе как о волевой, энергичной и самостоятельной личности, ожидание признания своей ценности и уникальности со стороны других людей, высокий уровень саморегуляции и настойчивости. Перспективу дальнейших исследований в этом направлении видим в изучении когнитивного и поведенческого компонентов самоэффективности с учетом гендерного аспекта.

Ключевые слова: самоэффективность, способность, саморегуляция, самопринятие, самоуважение, аутосимпатия, настойчивость.

Постановка наукової проблеми та її значення. Питання успішної самореалізації особистості в суспільстві, иї успіху в професійній та особистісній сферах, ефективного функціонування в соціумі все частіше привертають увагу науковців. Загалом сучасні глобалізаційні процеси та стрімкі зміни у світі ставлять перед людиною вимоги щодо наявності в неї таких якостей та характеристик, як гнучкість, мобільність, креативність, толерантність, упевненість, самостійність, наполегливість, самоприйняття, здатність володіти собою, самоконтроль тощо. Крізь призму зазначених вище понять психологи досліджують питання самоефективності особистості.

Особливої гостроти проблема самоефективності набуває в старшому шкільному віці, оскільки саме в цей період відбувається не лише професійне самовизначення школярів та визначення 3 планами на майбутнє загалом, а й певне усвідомлення власних здібностей, можливостей та шляхів самовдосконалення й саморозвитку. Саме віра в себе, свої можливості та спроможнісь здолати труднощі, розв'язати складні завдання постають відправною точкою подальшого успіху в житті молодої людини, досягненні цілей та розкритті акме.

Аналіз останніх досліджень із цісї проблеми. Перші спроби вивчення проблеми самоефективності можна простежити в працях філософів, які визначали їі як певне психічне утворення, пов'язане 3 цілеспрямованістю та впевненістю особистості, із почуттям власної гідності, самовдосконаленням.

У психології початок розробки поняття самоефективності пов'язують 3 ім'ям Альберта Бандури, який застосовував його швидше для 
цілеспрямованої роботи зі зміною особистості, а не для пояснення особистісного розвитку індивіда. Завдяки йому науковець оцінював спроможність людей до усвідомлення власних здібностей та їх найефективнішого застосування, зазначаючи, що навіть за наявності середніх здібностей уміле їх використання дає змогу людині досягати високих результатів. Згідно з його концепцією самоефективність не особистісна риса, а когнітивний механізм, який дає змогу суб'єкту аналізувати свої можливості під час виконання певних завдань, забезпечує актуалізацію його мотивації, форми поведінки й виникнення емоцій. Вона завжди усвідомлюється людиною, тобто є конструктом самосвідомості особистості, а також центральною й важливою детермінантою людської поведінки. Виокремлено специфічну (визначається контекстуально стосовно конкретного завдання, що постає перед людиною) та загальну (складається з окремих завдань, що існують у різних сферах людської діяльності) самоефективності (Bandura, 1977).

Дж. Маддукс і М. Шеєр пропонують виокремлювати самоефективність у діяльності та спілкуванні. Так, діяльнісна самоефективність - це переконання людини в тому, що власні компетенції й набутий раніше досвід у конкретному виді діяльності вона зможе застосовувати в аналогічній діяльності в майбутньому, досягнувши при цьому успіху. Самоефективність у спілкуванні являє собою самооцінку (уявлення) особистості про власну комунікативну компетентність у поєднанні з упевненістю, що відповідні компетенції вона зможе успішно застосовувати в ситуації взаємодії з людьми (Гальцева, 2015).

О. Рикель, розглядаючи професійну Я-концепцію, наголошує на необхідності вивчення саме професійної самоефективності як когнітивного компонента їі структури, який сприяє підвищенню успішності в професійній діяльності й рівня задоволеності нею (Рикель, 2011).

Т. Гордєєва пропонує розглядати самоефективність як продукт складного самопереконання в результаті когнітивного опрацювання інформації про власну особистість, із-поміж яких основними є безпосередній і опосередкований досвід, суспільна думка, фізичний та емоційний стан. Також розглянуто самоефективність як когнітивний предикатор мотивації досягнення (Гордеева, 2006). 
Зокрема, Т. Кремешна, визначаючи феномен самоефективності в межах педагогічної парадигми, наголошує на виокремленні поняття педагогічної самоефективності як інтегрального утворення, що виявляється у впевненості педагога у своїй компетентності, здатності продуктивно реалізовувати педагогічну діяльність, обираючи адекватні засоби педагогічного впливу задля успішного досягнення поставлених цілей навчально-виховного процесу (Кремешна, 2008).

М. Гайдар, досліджуючи самоефективність у процесі професійного становлення студентів-психологів, визначає іiі як метаякість, що являє собою комплекс уявлень суб'єкта щодо наявності в нього професійно важливих якостей та переконанні в можливості скористатися ними задля досягнення поставлених цілей і завдань. Науковець виокремлює види самоефективності: діяльнісну, комунікативну та особистісну. Саме особистісна самоефективність визначається ним як метаякість індивіда, тоді як комунікативна розглядається як уявлення студентів-психологів у наявності в них комунікативного потенціалу, який у подальшому сприятиме їхній успішності в царині професійного спілкування. Діяльнісна самоефективність трактується як переконаність відповідних осіб у сформованості в них знань, умінь, навичок та ефективному володінні професійними технологіями, а також упевненість у продуктивному застосуванні їх на практиці в майбутній професійній діяльності (Шапошник, 2011).

О. Музика, розглядаючи самоефективність як чинник професіоналізації студентів-першокурсників, аналізує не лише структуру, а й можливості розвитку іiі окремих компонентів у навчально-професійній діяльності. Авторка наголощує, що самоефективність спрацьовує лише за умови гарного самопочуття й помірного емоційного напруження, відсутність яких призводить до формування стійких особистісних диспозицій щодо неможливості досягнення успіху в професійному навчанні та майбутній професійній діяльності. Результати проведеного дослідження засвідчили про готовність студентів-першокурсників до розвитку професійної самоефективності і їх намагання дистанціюватися від негативних оцінок оточення, що можуть розхитувати їхню віру в себе та знижувати рівень самоповаги (Музика, 2018).

Отже, аналіз розглянутих підходів щодо феномену самоефективності засвідчує неоднозначність у розгляді цього поняття й потребу в його подальшому вивченні. 
Формулювання мети та завдань статті. Мета статті полягає в теоретичному огляді проблеми самоефективності в психології й визначенні особливостей вияву емоційно-вольового компонента самоефективності в старшому шкільному віці та передбачає виконання таких завдань, як аналіз стану дослідження проблеми самоефективності в психологічній літературі; емпіричне з'ясування особливостей прояву емоційно-вольового компонента самоефективності в старшокласників.

Методи та методики. Для досягнення поставленої мети застосовано такі методи, як теоретичні (порівняння, систематизація та узагальнення наукової інформації); організаційні (порівняльний метод дослідження); психодіагностичні, що представлені шкалою загальної самоефективності (Р. Шварцер, М. Срусалем), тестом на визначення самоефективності Дж. Маддукса й М. Шеєра (модифікація Л. Бояринцева, Р. Кричевського), тестом-опитувальником для визначення самоставлення С. Бодальова, С. Століна, тестом-опитувальником А. Звєрькова та С. Сйдмана; математичної статистики (визначення середньогрупових показників, відсотковий, однофакторний дисперсійний аналіз).

Виклад основного матеріалу й обгрунтування отриманих результатів дослідження. А. Бандура, вважаючи самоефективність ситуаційно-специфічним конструктом, із-поміж іiі характеристик виокремлює рівень, що відображає уявлення про завдання різного рівня складності, із якими особистість може успішно справитися; узагальненість, тобто широту уявлень про самоефективність особистості в різних сферах діяльності; силу, що являє собою ступінь упевненості особистості в можливості успішного виконання певного завдання. Ізпоміж основних компонентів самоефективності науковець виділяє когнітивний, що відображає уявлення індивіда про власну ефективність, впливає на процес прийняття рішень, виявляється в загальних здібностях; емоційний - демонструє емоційне ставлення особистості до власної ефективності та поведінковий, що реалізується в розгортанні поведінки завдяки впевненості у своїй здатності бути успішним у певному виді діяльності (Bandura Albert, 1977, Гордеева Т. О., 2006).

Ми пропонуємо дослідити саме емоційно-вольовий компонент самоефективності, який недостатньо вивчений у психології й репрезентований, з одного боку, емоційним ставленням індивіда під час оцінки власної особистості, референтами якої $є$ не лише показник 
самооцінки, а й усвідомлення своєї цінності, самоприйняття, наявність внутрішніх конфліктів, самоповага, самозвинувачення та аутосимпатія; із другого боку, уключає рівень вольової саморегуляції старшокласників, що виявляється в здатності до самоконтролю, наполегливості й спроможності доводити розпочату справу до кінця, володіти собою в різних ситуаціях, керувати свідомо своїми діями, станами та спонуканнями.

Дослідження проводили на базі 11-х класів Луцької спеціалізованої загальноосвітньої школи № 1 та Луцької загальноосвітньої школи № 15. Вибірку становили старшокласники віком 15-17 років загальною кількістю 80 осіб. Дослідження проводили у вересні-жовтні 2019 p.

Розподіл діагностованих на групи згідно з рівнем їхньої самоефективності за методикою «Шкала загальної самоефективності» (Р. Шварцер, М. Срусалем):

- група 1 - старшокласники із самоефективністю нижчою від середнього рівня (15\% осіб, із яких - сім хлопців та п’ять дівчат);

- група 2 - учні із середнім рівнем самоефективності (20\% осіб, шість хлопців і 10 дівчат);

- група 3 - респонденти із самоефективністю вищою від середнього рівня (65 \% опитаних, серед яких - 21 хлопець та 31 дівчина).

Учнів із низьким і високим рівнями самоефективності не виявлено.

Статистично значущі відмінності в показниках самоефективності діагностованих визначено в результатах першої та другої груп ( $\mathrm{F}=77,21$, при $\alpha \leq 0,001)$; першої й третьої ( $\mathrm{F}=235,2$, при $\alpha \leq 0,001)$; другої та третьої груп ( $\mathrm{F}=78,9$, при $\alpha \leq 0,001)$.

Середньогрупові показники школярів за тестом визначення самоефективності Дж. Маддукса й М. Шеєра (модифікація Л. Бояринцева, Р. Кричевського) зображено на рис. 1.

Отже, згідно з рис. 1, найвищі результати самоефективності у сферах діяльності та спілкування, порівняно 3 показниками трьох груп, визначено в діагностованих третьої групи (Хсер=4,67 i Хсер$=33,32$, відповідно), а найнижчі - у школярів першої групи $(\mathrm{Xcep}=-2,67$ та Хсер=14,08). В учнів із середнім рівнем самоефективності ці дані виявилися посередині (Хсер=1,43 й Хсер=24,06, відповідно). Тобто усереднені показники за сферами самоефективності засвідчують таке: у респондентів групи 1 виявлено низькі показники 
у сфері діяльності та середні - у спілкуванні. Учні із середнім рівнем i iз самоефективністю вищою від середнього рівня мають низькі показники у сфері діяльності та високі у сфері спілкування.

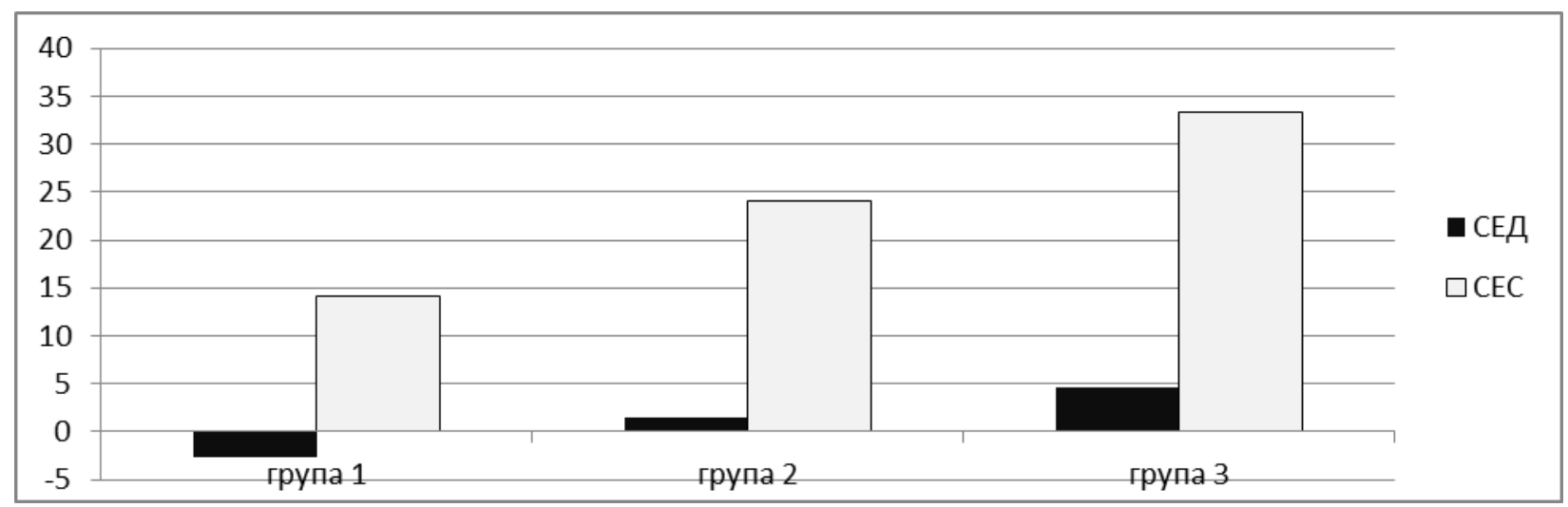

Рис. 1. Середньогрупові показники школярів трьох груп за тестом визначення самоефективності Дж. Маддукса й М. Шеєра

Примітка. СЕД - самоефективність особистості у сфері діяльності; CEC - самоефективність особистості у сфері спілкування.

Тобто старшокласники другої й третьої груп упевнено почуваються в ситуаціях спілкування 3 іншими людьми, не бояться першими виявити ініціативу, їм легко йти на контакт і знаходити нових друзів. Проте учні всіх трьох груп не завжди впевнені у своїх силах та доводять розпочату справу до кінця.

Завдяки однофакторному дисперсійному аналізу визначено статистично значущі відмінності в результатах самоефективності у сфері спілкування учнів першої й третьої груп $(\mathrm{F}=3,69$, при $\alpha \leq 0,05)$ та другої й третьої $(\mathrm{F}=3,18$, при $\alpha \leq 0,05)$, а також самоефективності у сфері діяльності першої та третьої груп $(\mathrm{F}=10,07$, при $\alpha \leq 0,01)$.

Усереднені результати трьох груп старшокласників за тестомопитувальником самоставлення С. Бодальова, С. Століна подано на рис. 2.

Опрацювання результатів за опитувальником самоставлення С. Бодальова, С. Століна (рис. 2) засвідчує таке:

- старшокласники із самоефективністю нижчою від середнього рівня, хоча й за всіма шкалами мають значно нижчі результати, проте найнижчі демонструють за шкалами самоприв'язаності $($ Хсер=3,58) та самовпевненості $(\mathrm{Xcep}=4,01)$. Тобто ці учні мають бажання щось у собі змінити, відчувають потребу відповідати ідеальному образу «Я» 
про себе, незадоволені собою й своїми можливостями, а також сумніваються в тому, що можуть викликати повагу оточення;

- учні із середнім рівнем самоефективності демонструють високий рівень самоприйняття (Xсер=5,8), внутрішньої конфліктності $(\mathrm{Xcep}=6,5)$ й самозвинувачення $(\mathrm{Xcep}=5,9)$. Отже, вони загалом дружньо ставляться до себе, схвалюють свої плани та бажання, намагаються приймати себе такими, якими $\epsilon$, навіть із недоліками; водночас бувають часто незгідні із собою й рефлексують із приводу власних недоліків, інколи переживають почуття провини, мають сумніви та зазвичай готові поставити собі в провину свої невдачі;

- у діагностованих старшокласників із самоефективністю вищою від середнього рівня, на відміну від решти груп, визначено високі показники за шкалами самовпевненості (X сер=6,5), самокерівництва $(\mathrm{Xcep}=6,3)$, дзеркального «Я» $(\mathrm{Xcep}=6,4)$ та самоцінності $(\mathrm{Xcep=7,3).} \mathrm{Тобто} \mathrm{вони} \mathrm{мають} \mathrm{уявлення} \mathrm{про} \mathrm{себе} \mathrm{як} \mathrm{про} \mathrm{самостійну,}$ вольову, енергійну й надійну особистість, яку $є$ за що поважати; упевнені, що є активними суб'єктами діяльності та мають внутрішній стрижень, а тому очікують на визнання своєї цінності іншими людьми; загалом ці школярі зацікавлені у власному «Я», прагнуть до самопізнання.

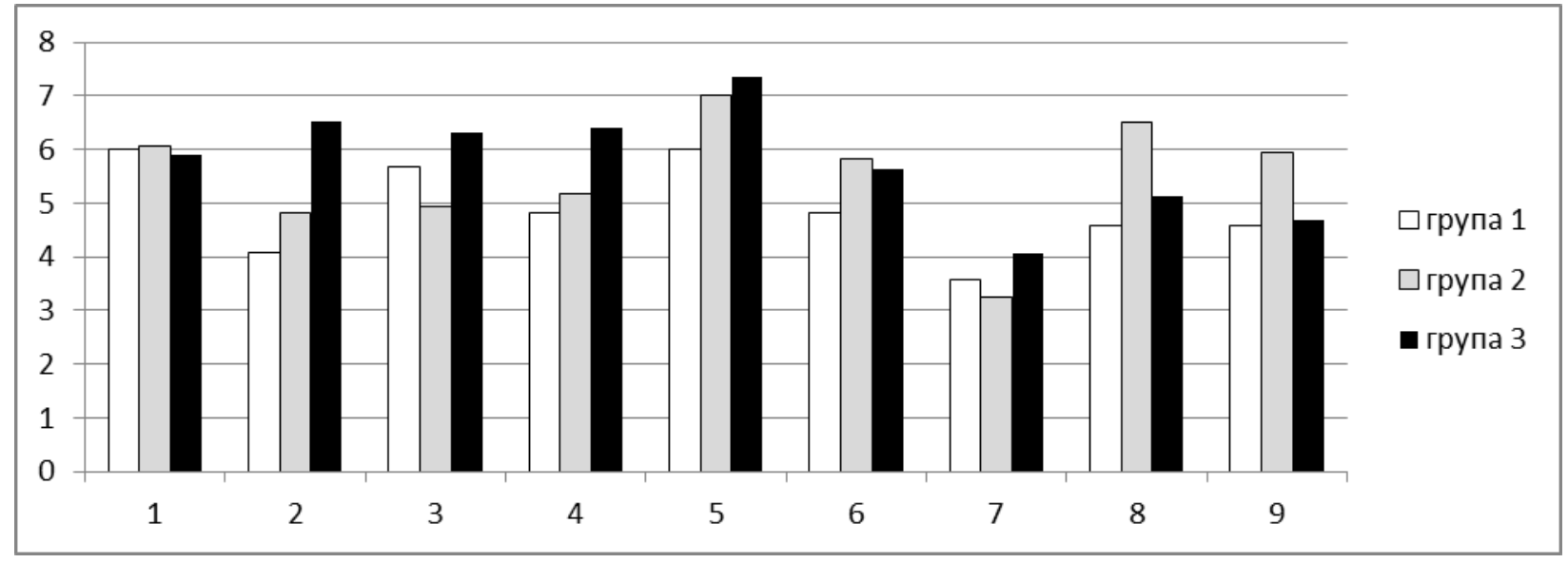

Рис. 2. Середньогрупові результати діагностованих за опитувальником самоставлення С. Бодальова, С. Століна

Примітка. 1 - внутрішня чесність, 2 - самовпевненість, 3 - самокерівництво, 4 - дзеркальне «Я», 5 - самоцінність, 6 - самоприйняття, 7 - самоприв'язаність, 8-внутрішня конфліктність, 9-самозвинувачення

Статистично значущі відмінності в результатах діагностованих визначено в учнів першої й другої груп за шкалами самовпевненості 
$(\mathrm{F}=3,74$, при $\alpha \leq 0,05)$ та конфліктності $(\mathrm{F}=5,8$, при $\alpha \leq 0,05)$; другої й третьої груп за шкалами самовпевненості ( $\mathrm{F}=21,03$, при $\alpha \leq 0,001)$, самокерівництва ( $\mathrm{F}=8,6$, при $\alpha \leq 0,001)$, дзеркального «Я» $(\mathrm{F}=3,7$, при $\alpha \leq 0,05)$, самоприв'язаності ( $\mathrm{F}=3,9$, при $\alpha \leq 0,05)$, конфліктності ( $\mathrm{F}=7,7$, при $\alpha \leq 0,01)$ і самозвинувачення (F=3,79, при $\alpha \leq 0,05)$; першої й третьої груп за шкалами самовпевненості ( $\mathrm{F}=33,03$, при $\alpha \leq 0,001)$, дзеркального «Я» $(\mathrm{F}=5,3$, при $\alpha \leq 0,05)$ та самоцінності $(\mathrm{F}=5,03$, при $\alpha \leq 0,05)$.

Середньогрупові результати діагностованих за тестом-опитувальником А. Звєрькова і Є. Сйдмана дають змогу стверджувати про таке:

- в учнів третьої групи встановлено високі за шкалами загального рівня саморегуляції (Xсер=14,69) і наполегливості (Xсер=10,04). Тобто ці старшокласники вирізняються здатністю до володіння собою, упевненістю в собі, стійкістю намірів, розвиненим почуттям обов'язку, прагненням завершити розпочату справу та мобілізованістю під час подолання перешкод;

- високі результати старшокласники другої групи продемонстрували лише за шкалою самоконтролю $(\mathrm{Xcep=8),} \mathrm{усі} \mathrm{інші} \mathrm{показники}$ перебувають у середньому діапазоні (Хсер=12,93 - загальний рівень саморегуляції й Хсер=8,43 - за шкалою наполегливості), тобто ці учні теж прагнуть до завершення розпочатої справи та мобілізовані в доланні перешкод, до того ж вони також спроможні до контролю власних емоційних станів і реакцій;

- на відміну від вищезгаданих груп, школярі першої групи мають нижчі показники за всіма шкалами загального рівня саморегуляції $(\mathrm{Xcep}=10,75)$, наполегливості $(\mathrm{Xcep}=7,08)$ й самоконтролю $(\mathrm{Xcep}=6)$. Тобто вони не завжди завершують розпочату справу, часто можуть не контролювати власні емоційні стани та реакції, бувають не впевнені у своїх силах, можливостях і здібностях.

Статистично значущі відмінності в результатах діагностованих визначено в першій і третій групах за шкалами загального рівня саморегуляції $(\mathrm{F}=6,88$, при $\alpha \leq 0,01)$ та наполегливості $(\mathrm{F}=8,3$, при $\alpha \leq 0,01)$.

Висновки та перспективи подальших досліджень. Самоефективність - складний психологічний конструкт, який розглядають переважно як здатність до усвідомлення особистістю своїх здібностей і їх найефективнішого застосування, що містить когнітивний, емоційний та поведінковий компоненти. Виокремлюють такі види само- 
ефективності, як діяльнісна, комунікативна й особистісна. У старшому шкільному віці самоефективність пов'язана 3 усвідомленням сенсу та мотивів навчання, автономністю, професійним самовизначенням, позитивним самоставленням, самоповагою, самокерівництвом і спроможністю до самоорганізації загалом.

Проведене емпіричне дослідження дає підставу констатувати таке:

- старшокласників із низьким та високим рівнями самоефективності не виявлено; результати діагностованих перебувають у межах іiі середнього рівня (15\% осіб - нижче від середнього рівня; $20 \%$ - із середнім рівнем і $65 \%$ - із самоефективністю вищою від середнього рівня); усі три групи респондентів не завжди впевнені у своїх силах та доводять розпочату справу до кінця, проте в ситуаціях спілкування школярі із середнім і вищим від середнього рівнями самоефективності не бояться виявляти ініціативу та легко йдуть на контакт;

- визначено такі особливості прояву емоційно-вольового компонента самоефективності в старшому шкільному віці: в осіб із самоефективністю нижчою від середнього рівня - потреба відповідати ідеальному образу «Я» й бажання змін, проте незадоволеність, тривожність та сумніви в собі, своїх можливостях і здібностях, сором'язливість, неспроможність контролювати власні емоційні стани та реакції; в учнів із середнім рівнем самоефективності - високий рівень самоприйняття, водночас внутрішня конфліктність та самозвинувачення, рефлексування 3 приводу власних недоліків і невдач, переживання почуття провини, проте прагнення завершувати розпочату справу та мобілізованість у доланні перешкод, а також самоконтроль емоційних станів і реакцій; у діагностованих із самоефективністю вищою від середнього рівня - самовпевненість, усвідомлення власної цінності, самокерівництво, уявлення про себе як про вольову, енергійну й самостійну особистість, очікування визнання своєї цінності та унікальності з боку інших людей, високий рівень саморегуляції й наполегливості.

Перспективу подальших розвідок у цьому напрямі вбачаємо у вивченні когнітивного та поведінкового компонентів самоефективності з урахуванням гендерного аспекту.

\section{Література}

1. Гальцева, Т. О. (2015). Види самоефективності особистості: їх характеристика та дослідження. Науковий вісник Херсонського державного університету. Серія: Психологічні науки, 4, 110-114. 
2. Гордеева, Т. О. (2006). Психология мотивации и достижения. Москва: Смысл; Академия.

3. Кремешна, T. I. (2008). Педагогічна самоефективність як умова успішного викладання. Наука і освіта: наук.-практ. журн. Південного наук. центру АПН України, 1-2, 58-61.

4. Музика, О. (2018). Самоефективність як чинник професіоналізації студентів. Освітологічний дискурс, 3-4(22-23), 83-94.

5. Рикель, А. М. (2011). Профессиональная Я-концепция и профессиональная идентичность структуре самосознания личности. Психологические исследования: электрон. науч. журн., 2 (16). URL: http://psystudy.ru

6. Шапошник, Д. О. (2011). Ресурси теорії самоефективності особистості у сучасній психології. Вісник Харківського національного університету. Серія: Психологія, 937, 302-305.

7. Bandura, Albert (1977). Self-effecacy: Toward a Unifying Theory of Behavioral Change. Psychological Review, 84(2), 191-215.

8. Bandura, A. (1982). Self-efficacy mechanism in human agency. American Psychologist, 37, 122-147.

\section{References}

1. Haltseva, T. O. (2015). Vydy samoefektyvnosti osobystosti: yikh kharakterystyka ta doslidzhennia [Types of self-efficacy of the individual: their characteristics and research]. Naukovyi visnyk Khersonskoho derzhavnoho universytetu. Seriia: Psykholohichni nauky - Scientific Bulletin of Kherson State University. Psychological Sciences Series, 4, 110-114 (in Ukrainian).

2. Hordeeva, T. O. (2006) Psykholohyia motyvatsyy dostyzhenyia [Psychology of motivation and achievement]. Moskva: Smysl; Akademyia (in Russian).

3. Kremeshna, T. I. (2008) Pedahohichna samoefektyvnist yak umova uspishnoho vykladannia [Pedagogical self-efficacy as a condition for successful teaching]. Nauka i osvita: naukovo-praktychnyi zhurnal Pivdennoho naukovoho tsentru APN Ukrainy - Science and education: scientific and practical journal of the Southern Scientific Center of the Academy of Pedagogical Sciences of Ukraine, 1-2, 58-61 (in Ukrainian).

4. Muzyka, O. (2018). Samoefektyvnist yak chynnyk profesionalizatsii studentiv. Osvitolohichnyi dyskurs, 3-4(22-23), 83-94 (in Ukrainian).

5. Rykel, A. M. (2011). Professyonalnaya Ya-kontseptsyia i professyonalnaia identychnost strukture samosoznaniya lichnosty [Professional self-concept and professional identity to the structure of self-identity]. Psykholohycheskiy issledovaniya: elektr. nauch. Zhurnal - Psychological research: electronic scientific journal, 2 (16). URL: http://psystudy.ru (in Russian).

6. Shaposhnyk, D. O. (2011). Resursy teorii samoefektyvnosti osobystosti u suchasnii psykholohii [Resources of the theory of self-efficacy of personality in modern psychology]. Visnyk Kharkivskoho natsionalnoho universytetu. Seriia 
«Psykholohiia»-Bulletin of Kharkiv National University. Psychology Series, 937, 302-305 (in Ukrainian).

7. Bandura, A. (1977) Self-effecacy: Toward a Unifying Theory of Behavioral Change. Psychological Review, 84(2), 191-215 (in American).

8. Bandura, A. (1982). Self-efficacy mechanism in human agency. American Psychologist, 37, 122-147 (in American).

Received: 04.02.2020

Accepted: 25.02.2020 